\title{
BIMBINGAN DAN KONSELING BELAJAR (AKADEMIK) DALAM PERSPEKTIF ISLAM
}

\author{
Yuni Novitasari', Muhammad Nur ${ }^{2}$
}

\begin{abstract}
The goal of national education as set forth in the Law of the Republic of Indonesia looks not only focused on the development of cognitive but also affective, and psychomotor. To realize the quality of the knowledge of the learner, the learning experience (academic) becomes so important. Learning gains are not limited to the cognitive but also the character of the students. Learning is a way to acquire knowledge is a precious suggestion in Islam. The subject teachers as facilitators in helping students learn. Similarly, guidance and counseling teachers, in the field of academic, guidance and counseling teacher seeks to help learners to understand themselves and their environment so that learners are able to adapt and fulfill the task of learning (academic) it well. This study aims to produce a study on the Islamic perspective regarding guidance and counseling learning (academic). The method used is the study of literacy. With reviewing or studying libraries or literacy, both print and electronic that have a study on the topic. Based on the results of the study, it can be concluded that the counseling and guidance of learning (academic) aims to help facilitate the individual in the learning process. So in the view of Islam, teacher guidance and counseling have a glorious opportunity to teach goodness and benefits for other people especially in the study.
\end{abstract}

Keywords: Guidance and Counseling, Islam, Learning (Academic).

\section{PENDAHULUAN}

Bimbingan dan konseling belajar merupakan suatu mata kuliah yang harus ditempuh para mahasiswa bimbingan dan konseling. Dalam mata kuliah ini, mahasiswa dituntut untuk menguasai teori maupun praktik bimbingan dan konseling belajar. Pengertian bimbingan dan konseling belajar adalah suatu proses bantuan untuk memfasilitasi siswa dalam mengembangkan pemahaman dan keterampilan dalam belajar atau akademik (Yusuf, 2009). Tujuan umum bimbingan dan konseling belajar ialah membantu para mahasiswa bimbingan dan konseling, yang notabennya calon guru bimbingan dan konseling agar dapat membantu para peserta didiknya kelak memiliki perkembangan belajar atau akademik yang lebih baik, yang meliputi: mampu mengatasi kesulitan belajar, masalah belajar, memiliki movitasi belajar dan mengembangkan keterampilanketerampilan yang mendukung pencapaian akademik yang lebih optimal.

Sebagai upaya pengintegrasian nilai-nilai Islam dalam materi mata kuliah tersebut sebagaimana yang di usung dalam catur dharma Universitas kami, yaitu

\footnotetext{
I Program Studi Bimbingan dan Konseling Fakultas Keguruan dan Ilmu Pendidikan (FKIP) Universitas Muhammadiyah Metro, Lampung; yuni_bkumm@gmail.com.

2 Universitas Muhammadiyah Metro, Lampung; abusaamih@gmail.com.
} 
Universitas Muhammadiyah Metro, maka pengkajian nilai-nilai Islam yang terkait dengan materi mata kuliah bimbingan dan konseling belajar amatlah diperlukan. Sebagaimana tujuan pendidikan nasional (UU tahun 2003 bab II pasal 2) adalah untuk berkembangnya potensi peserta didik agar menjadi manusia yang beriman dan bertakwa kepada Tuhan Yang Maha Esa, berakhlak mulia, sehat, berilmu, cakap kreatif, mandiri dan menjadi warga negara yang demokratis serta bertanggungjawab. Tampak jelas bahwa upaya pendidikan nasional di sekolah maupun di perguruan tinggi tidaklah semata-mata membekali pengetahuan dan keterampilan dalam bidang ilmu tersebut, tetapi lebih dari itu ialah mengembangkan karakter peserta didiknya yang salah satunya ialah karakter beriman dan bertakwa kepada Tuhan Yang Maha Esa.

Untuk mengembangkan karakter beragama para peserta didik, tentu tidaklah cukup hanya dibekali ilmu-ilmu umum saja, tetapi akan lebih maksimal bila pengajar atau dosen bisa memasukan nilai-nilai agama tersebut di setiap materi pembelajaran. Oleh karenanya kajian menurut perspektif agama tentang suatu materi kuliah amatlah bermanfaat. Dalam penelitian ini, peneliti tertarik mengangkat sebuat kajian tentang bimbingan dan konseling belajar dalam perspektif Islam.

Bimbingan dan konseling belajar merupakan salah satu mata kuliah wajib yang harus diikuti oleh mahasiswa bimbngan dan konseling, sebagai calon guru bimbingan dan konseling di sekolah. Melalui mata kuliah ini, diharapkan mahasiswa bimbingan dan konseling mengatahui dan memahami teori dan praktik bimbingan dan konseling belajar (akademik). Bimbingan dan konseling belajar merupakan proses bantuan untuk memfasilitasi siswa dalam mengembangkan pemahaman dan keterampilan dalam belajar, dan memecahkan masalah-masalah belajar atau akademik (Yusuf, 2009). Dengan demikian, guru bimbingan dan konseling bisa menerapkan fungsi pencegahan, pemeliharaan, pengembangan, perbaikan ataupun penyembuhan dalam layananlayanan bimbingan dan konseling belajar.

Yusuf dan Nurihsan (2009) menyebutkan beberapa tujuan bimbingan dan konseling yang terkait dengan aspek akademik (belajar) adalah agar peserta didik: (I) memiliki sikap dan kebiasaan belajar yang positif, (2) memiliki motibasi yang tinggi untuk belajar, (3) memiliki teknik atau keterampilan belajar yang efektif, (4) memiliki keterampilan untuk menetapkan tujuan dan perencanaan pendidikan, dan (5) memiliki kesiapan mental dan kemampuan menghadapi ujian. Untuk mewujudkan tujuan tersebut, maka para mahasiswa sebagai calon 
guru bimbingan dan konseling harus memiliki bekal yang memadahi tentang teori dan praktik bimbingan dan konseling belajar (akademik).

Menurut kurikulum nasional yang telah disepakati oleh Asosiasi Bimbingan dan Konseling Indonesia (ABKIN) di Surabaya tahun 2009, bahwa mata kuliah bimbingan dan konseling belajar adalah mata kuliah yang memberikan pembekalan pengetahuan kepada mahasiswa berkenaan dengan konsep-konsep belajar dan layanan bimbingan dan konseling belajar. Berdasarkan deskripsi dalam kurikulum tersebut dan disertai kajian teoritis tentang bimbingan dan konseling belajar, maka peneliti merumuskan ada 6 (enam) pokok bahasan yang harus dikaji dalam bimbingan dan konseling belajar, diantaranya: (I) pengertian dan wawasan pembelajaran, (2) konsep bimbingan dan konseling belajar, (3) program bimbingan dan konseling belajar, (4) layanan-layanan bimbingan dan konseling belajar, (5) diagnosis kesulitan belajar, dan (6) prosedur pengajaran remedial. Secara umum, keenam pokok bahasan tersebut mencakup tiga hal utama yakni: (I) wawasan tentang pembelajaran, (2) konsep bimbingan dan konseling belajar, dan (3) upaya guru bimbingan dan konseling dalam kegiatan bimbingan dan konseling belajar. Oleh karena itu, kajian bimbingan dan konseling belajar menurut perspektif Islam di sini akan mengkaji sudut pandang Islam tentang tiga hal utama dalam bahan ajar bimbingan dan konseling belajar.

Sutoyo (2013) menyebutkan hakikat bimbingan dan konseling Islami adalah upaya membantu individu belajar mengembangkan fitrah-imandan atau kembali kepada fitrah-iman, dengan cara memberdayakan (enpowering) fitrahfitrah (jasmani, rohani, nafs dan iman) mempelajari dan melaksanakan tuntunan Allah dan Rasul-Nya, agar fitrah-fitrah yang ada pada individu berkembang dan berfungsi dengan baik dan benar. Pada akhirnya diharapkan agar individu selamat dan memperoleh kebahagiaan yang sejati di dunia dan akhirat. Maka kajian tentang bimbingan dan konseling belajar dalam perpesktif Islam akan di arahkan untuk melihat ke 3 (tiga) bahasan utama bimbingan dan konseling belajar berdasarkan perspektif atau sudut pandang Islam, yakni memandangnya sesuai fitrah manusia sebagai mahkluk ciptaan Allah SWT yang semestinya berpedoman pada Alquran dan hadist dalam menjalani kehidupan sehari-hari.

Sebagaimana tujuan pendidikan nasional (UU tahun 2003 bab II pasal 2) adalah untuk berkembangnya potensi peserta didik agar menjadi manusia yang beriman dan bertakwa kepada Tuhan Yang Maha Esa, berakhlak mulia, sehat, berilmu, cakap kreatif, mandiri dan menjadi warga negara yang demokratis serta bertanggungjawab. Uraian tujuan pendidikan nasional tersebut menyiaratkan bahwa negara ini mengharapkan terwujudnya generasi-generasi hasil pendidikan 
kita yang tidak hanya memiliki ilmu pengetahuan, keterampilan dan keahlian di bidang tertentu, tetapi juga memiliki karakter yang luhur, yang salah satunya karakter beriman dan bertakwa kepada Tuhan Yang Maha Esa. Dalam pancasila sebagai cermin dan tuntutan kepribadian warganegara Indonesia pun menyebutkan pada sila pertama bahwa tiap warganegara Indonesia harus berkeTuhanan Yang Maha Esa, yang artinya harus meyakini adanya Tuhan Yang Maha Esa, sesuai dengan agama yang di akui oleh negara kita dan sesuai dengan keyakinan masing-masing pribadi. Seiring dengan keyakinan kepada Tuhan Yang Maha Esa, tentu di barengi dengan aktivitas takwa, yang asrti menjalankan segala perintahNya dan menjauhi laranganNya. Bila seorang Muslim hendaknya ia menjalankan perintah Allah SWT dan menjauhi laranganNya sebagaimana yang tertuang dalam Hadist dan kitab suci Alquran. Tentunya pribadi warga negara yang bertakwa akan berdampak positif dalam berkarya mengisi pembangunan bangsa.

Disebutkan juga dalam Peraturan Pemerintah RI No. 19 Tahun 2005 bab $\checkmark$ bahwa standar kelulusan pada jenjang pendidikan tinggi bertujuan untuk mempersiapkan peserta didik menjadi anggota masyarakat yang berakhlak mulia, memiliki pengetahuan, keterampilan, kemandirian, dan sikap untuk menemukan, mengembangkan, serta menerapkan ilmu, teknologi, dan seni, yang bermanfaat bagi kemanusiaan. Rincian standar lulusan tersebut pun searah dengan tujuan pendidikan nasional, yakni pengembangan karakter menjadi bagian dari standar lulusan yang diharapkan. Untuk mewujudkan lulusan perguruan tinggi yang berilmu dan terampil serta memiliki karakter takwa tentu perlu didukung tidak hanya dari pembekalan ilmu-ilmu yang bersifat umum, melainkan perlu pembekalan tentang ilmu yang bernilai agama, dalam hal ini Islam. Dengan demikian, pengintegrasian nilai-nilai Islam dalam materi pelajaran amatlah diperlukan.

Pengintegrasian nilai-nilai Islam dalam materi kuliah terutama pada kuliah bimbingan dan konseling belajar tentu amatlah membantu, karena tenaga profesi bimbingan dan konseling sangat dituntut pengembangan karakter atau akhlak disamping kemampuan akademis. Dengan demikian, tentu akan mendukung terwujudnya tenaga-tenaga bimbingan dan konseling yang cerdas dan juga bermartabat (profesional) sehingga mereka turut mendukung terwujudnya generasi berikutnya yang juga cerdas dan bermartabat yang berlandaskan takwa. Munir (2013) menyebutkan bimbingan dan konseling dalam Islam memiliki tujuan sebagai berikut: (I) menghasilkan suatu perubahan, perbaikan, kesehatan, dan kebersihan jiwa dan mental; (2) menghasilkan suatu 
perubahan, perbaikan, dan kesopanan tingkah laku yang dapat memberikan manfaat, baik pada diri sendiri, maupun lingkungannya; (3) menghasilkan kecerdasan rasa (emosi) pada individu; (4) menghasilkan kecerdasan spiritual pada diri individu; dan (5) menghasilkan potensi ilahiah, maka individu dapat melakukan tugasnya sebagai khalifah dengan baik dan benar, dapat menanggulangi berbagai persoalan hidup dan memberi manfaat bagi lingkungannya.

\section{METODE}

Desain Penelitian yang digunakan adalah studi pustaka. Studi pustaka adalah segala usaha yang dilakukan oleh peneliti untuk menghimpun informasi yang relevan dengan topik atau masalah yang akan atau sedang diteliti. Informasi itu dapat diperoleh dari buku-buku ilmiah, laporan penelitian, karangankarangan ilmiah, tesis dan disertasi, peraturan-peraturan, ketetatapanketetapan, buku tahunan, ensiklopedia, dan sumber-sumber tertulis baik tercetak maupun elektronik lain. Analisis data hasil penelitian dilakukan dengan meninjau kembali kesesuaian antara hasil temuan dengan tujuan penelitian yang ditetapkan, selanjutnya hasil penelitian diuji isinya oleh dua ahli agama Islam, dan dua ahli bimbingan dan konseling.

\section{DISKUSI}

\section{Hakikat Manusia Dalam Perspektif Psikologi}

Bicara mengenai manusia, tentu tidak terlepas dari kajian ilmu psikologi yang merupakan suatu bidang ilmu yang mempelajari seluk-beluk perilaku dan jiwa manusia. Sejauh ini, ada empat pandangan/aliran dalam ilmu psikologi diantaranya; psikoanalisis, psikologi perilaku, psikologi humanistik, dan psikologi transpersonal (Bustaman: 201I, Cuningham: 201I, Corey: 1995). Masingmasing aliran memiliki pandangan tersendiri mengenai sosok manusia. Psikoanalisis lebih memandang manusia merupakan makhluk yang dominan cenderung mencari kenikmatan dan menghindari ketidaknyamanan, pandangan ini begitu menekankan besarnya pengaruh alam bawah sadar dalam mempengaruhi perilaku seseorang, alam bawah sadar ini disebut id atau dengan kata lain nafsu. Pandangan psikoanalisis juga menjelaskan tentang bagian jiwa lainnya, yakni disebut ego (alam realita) dan super ego (alam idealitas). 
Aliran psikologi perilaku memandang bahwa perilaku manusia banyak dipengaruhi oleh faktor-faktor luar di dalam dirinya. Pandangan ini menganggap manusia pada hakikatnya netral. Perilaku baik atau buruk seseorang dipengaruhi oleh situasi dan keadaan lingkungan. Oleh karenanya, aliran ini menyarankan beberapa treatment pengkondisian lingkungan dalam mengubah atau memodifikasi perilaku manusia.

Aliran humanistik lebih memandang potensi baik pada manusia, bahkan lebih cenderung banyak baiknya dari pada buruknya. Psikologi humanistik lebih memusatkan perhatian untuk menelaah kualitas-kualitas insani, yakni sifat-sifat dan kemampuan khusus manusia yang terpatri pada eksistensi manusia, seperti kemampuan abstraksi, daya analisis dan sintesis, imajinasi, kreativitas, kebebasan berkehendak, tanggungjawab, aktualisasi diri, makna hidup, pengembangan pribadi, humor, sikap etis, dan rasa estetika (Bastaman: 20I I).

Perhatian psikologi transpersonal terpusat pada studi tentang potensi tertinggi manusia, dengan merekognisi, memahami, dan merealisasi kondisi kesadaran tentang kesatuan, spiritual dan kekuatan diatas rata-rata manusia (Shapiro: 1992, Frederickson \& Anderson: 1999, Shapiro, Lee, \& Gross: 2002). Aliran ini telah mulai mempelajari fenomena kebutuhan dan kemampuan spiritual manusia. Dikatakan bahwa pandangan transpersonal dapat membuka jalan untuk kajian mengenai agama (Chuningham: 20l3). Dengan demikian, perkembangan kajian psikologi modern hakikat manusia tidak lagi sebatas kebutuhan jasmani dan rohani dasar manusia, tapi juga mengkaji fenomena spiritual dalam jiwa manusia.

\section{Karakteristik Manusia Dalam Perspektif Islam}

Dalam pandangan Islam, manusia dan seluruh makhluk di muka bumi ini diciptakan oleh Allah SWT. Manusia tercipta dari tanah. Allah SWT telah menciptakan manusia dengan lebih sempurna dari mahkluk-makhluk lain. Kesempurnaan tersebut terdapat pada akal pikiran manusia yang lebih sempurna dari mahkluk yang lain.

Najati (200I) menjelaskan ada beberapa dorongan tingkahlaku manusia yang tersirat berdasarkan penjelasan di Alquran; dorongan fisiologis, dorongan psikis dan spiritual, dan dorongan bawah sadar. Dorongan fisiologis berupa dorongan menjaga diri, kelestarian keturunan, dorongan seksual, dan dorongan keibuan. Dorongan psikis dan spiritual meliputi; dorongan psikis, spiritual, dorongan memiliki, dorongan memusuhi, dorongan berkompetisi, dan dorongan beragama. Dorongan bawah sadar seperti merasakan adanya 
keinginan dorongan yang tidak bisa diterima akal, atau menimbulkan kegelisahan, kemudian berusaha menjauhkannya dari wilayah kesadaran atau perasaannya, sehingga menekan alam bawah sadar lalu menimbulkan suatu bentu perilaku, misalnya seperti terpeleset lidah atau salah ucap. Diantara beberapa dorongan tersebut, Najati (200I) juga menjelaskan tentang adanya konflik antar dorongan, upaya pengendalian dorongan, dan juga penyimpangan dorongan.

Konflik antar dorongan ini menghasilkan sikap ragu-ragu dan juga binggung. Misalnya, ada seseorang yang ingin mengambil hak orang lain, tetapi di sisi lain ia ingat kepada Allah. Sikap ragu-ragu telah cukup banyak dijelaskan dalam Alquran. Sebagaimana "apakah kita akan menyeru selain daripada Allah, sesuatu yang tidak dapat mendatangkan kemanfaatan kepada kita dan (apakah) kita, seperti orang-orang yang telah disesatkan oleh setan di pesawangan yang menakutkan, dalam keadaan bingung, dia mempunyai kawan-kawan yang memanggilnya kepada jalan yang lurus (dengan mengatakan); "Marilah ikut kami” (QS: Al an'am/ 6:7I). Terdapat pula penjelasan ayat yang menceritakan tentang kondisi bingung pada diri manusia (QS at taubah 9: 45, an nisa 4: 143, dan an nisa 4: 90). Dengan demikian, Islam mengajarkan agar manusia senantiasa berpegang teguh pada petunjuk dan perintah Allah dengan yakin, agar memperoleh keberuntungan yang sesungguhnya.

Berdasarkan ayat-ayat Alquran dan keterangan dari Rasulullah di temukan beberapa "sifat khas" (karakteristik) manusia yang membedakan dengan makhluk lain (Sutoyo: 2013), karakteristik itu diantaranya:

I) Manusia diciptakan Allah terdiri dari 2 undur yang tidak bisa dipisahkan satu sama lai, yaitu unsur jasmani dan ruh Illahi (akal dan ruhani). Unsur rohani merupakan unsur yang mengantarkan manusia lebih mampu mengenal Allah SWT, beriman, berbudi pekerti luhur, serta berperasaan halus. Jasmani merupakan aspek biologis yang dipersiapkan sebagai wadah rohani.

2) Manusia sejak asal kejadiannya dilengkapi dengan "fitrah beragama" yaitu mengakui keesaan Allah dan tunduk kepada-Nya.

3) Manusia diciptakan Allah dilengkapi dengan akal pikiran, yang memungkinkan manusia mampu membedakan antara yang benar dengan salah, antara yang bermanfaat dan tidak bermanfaat bagi dirinya.

4) Manusia diciptakan Allah dilengkapi dengan perasaan yang memungkinkan manusia mengetahui hal-hal yang tersembunyi dan halus. Bisa jadi manusia secara inderawi tidak melihat peristiwa yang menimpa oranglain, tetapi 
melalui perasaannya dia bisa mengetahui objek yang tidak dilihatnya itu. Imam Gazali (2003) mengilustrasikan bahwa orang-orang yang senantiasa mentaati aturan Allah dan Rasul-Nya diibaratkan bagai "cermin yang bersih". Orang beriman secara kafah mampu memandang fenomena berdasarkan mata hatinya yang senantiasa suci. Ibarat kaca yang bersih dapat menampilkan gambar-gambar yang jelas, sementara kaca yang kotor tidak mampu menampilkan gambar secara jelas.

5) Kemampuan manusia untuk mengetahui beberapa hal sangat terbatas, bahkan manusia tidak tahu kecuali sekedar tanda-tandanya kapan datangnya hari kiamat.

6) Manusia diciptakan Allah dengan hati nurani (fu,ad) dan qalb, tidak seperti jenis hewan yang hanya dilengkapi dengan pendengaran dan penglihatan. Dengan hati, memungkinkan manusia memikirkan apa yang di luar alam inderawi beserta rinciannya. Kemudian mengantarkannya kepada yang sifatnya umum, dan pada gilirannya menghasilkan hukum-hukum yang bersifat umum dan menyeluruh.

7) Manusia ditetapkan tempat tinggalnya di bumi hingga batas waktu yang ditentukan Allah. Pada binatang tidak ada balasan surga atau dari neraka akibat dari perbuatannya, sedang manusia akan dimintai tenggungjawab dari apa yang diperbuatnya sebelum ia ditetapkan tinggalnya di surga atau neraka.

8) Manusia tidak sepenuhnya mampu menguasai dan memelihara dirinya sendiri, karena tidak sedikit hal-hal yang di luar kemampuannya. Banyak hal yang manusia menduga baik, tetapi terbukti merugikan dirinya sendiri. Pengetahuan manusia terhadap dirinya sendiri juga terbatas. Setiap individu diikuti dua malaikat yang selalu mengikutinya secara bergiliran di depan dan di belakangnya. Mereka menjaganya atas perintah Allah.

9) Manusia selalu diawasi oleh dua malaikat yang selalu mencatat apa yang dilakukan, baik itu perbuatan baik atau buruk. Catatan itu kelak akan disodorkan kepada manusia di hari kemudian dalam bentuk kitab catatan amal.

10) Setiap individu akan mendapatkan balasan dari apa yang ia perbuat, bagi individu yang takut kepada Allah dan ia mampu menguasai hawa nafsunya, maka tempatnya adalah di surga. Jika ada individu yang terjerumus ke dalam neraka adalah karena perbuaannya sendiri.

Manusia memang memiliki kemampuan yang istimewa dibanding mahkluk Allah lainnya, diantaranya keistimewaannya manusia dikaruniai akal, hati nurani 
dan juga keimanan. Manusia dapat mengembangkan dirinya menuju derajat kemuliaan setinggi-tingginya, atau bahkan sebaliknya bisa terjerumuskan pada derajat yang serendah-rendahnya. Kemuliaan seseorang dalam Islam terukur dari kualitas iman dan takwanya (yang tentu perlu dipahami secara luas). Oleh karenanya, manusia juga disebut mahkluk lemah, yang sejatinya selalu membutuhkan pertolongan Allah. Dengan demikian, manusia perlu melakukan upaya pengembangan diri untuk menjemput pertolongan dari Allah guna memperoleh kebaikan di dunia dan akhirat.

\section{Tujuan Penciptaan Manusia Dalam Perspektif Islam}

Adapun tujuan penciptaan manusia pun telah tersebutkan didalam Alquran, Surat Al-Baqarah (30) "Ingatlah ketika Tuhanmu berfirman kepada para malaikat: sesungguhnya Aku hendak menjadikan seorang khalifah di muka bumi, Mereka berkata; Mengapa engkau hendak menjadikan (khalifah) di bumi itu orang yang akan membuat kerusakan padanya dan menumpahkan darah, padahal kami senantiasa bertasbih dengan memuji engkau? Tuhan berfirman; sesungguhnya Aku mengetahui apa yang tidak kamu ketahui”.

Shihab (2000) mentafsirkan, bahwa kata khalifah pada mulanya berarti yang mengantikan atau yang datang sesudah siapa yang datang sebelumnya. Terkait hal ini, Sutoyo (2013) mengartikan bahwa esensi tujuan penciptaan manusia adalah Allah hendak memberi tugas kepada manusia sebagai khalifah Allah di bumi, yaitu melaksanakan amanah sesuai tuntunan Allah dan Rasul-Nya dalam bidang keahlian dan atau kewenangan sesuai yang dikaruniakan Allah kepadanya.

Surat Ad-Dzariyat (56-58) menyebutkan “Dan aku tidak menciptakan jin dan manusia melainkan supaya mereka menyembah-Ku. Aku tidak menghendaki rezki sedikitpun dari mereka dan aku tidak menghendaki supaya mereka memberi Aku makan. Sesungguhnya Allah Dialah Maha Pemberi rezeki Yang Mempunyai Kekuatan lagi Sangat kukuh. Terkait hal ini, Sutoyo (2013) menjelaskan bahwa tujuan penciptaan manusia itu bukan untuk Allah, tetapi untuk diri manusia itu sendiri. Jadi bila dalam ayat tersebut dikatakan agar manusia beribadah itu bukan untuk Allah tetapi untuk manusia itu sendiri. Disamping itu, cakupan ibadah yang harus dilaksanakan manusia bukan hanya pada saat-saat tertentu saja, melainkan sepanjang hidupnya. Ibadah dikelompokan menjadi "ibadah mahdhah" dan "ghairu mahdhah". Ibadah mahdah adalah ibadah yang telah ditentukan oleh Allah, bentuk, kadar, atau waktunya, seperti shalat, puasa, zakat, dan haji. Ibadah ghairu mahdhah 
merupakan semua aktivitas lahir dan batin manusia yang dilakukan yang diniatkan tulus untuk memperoleh ridho Allah.

Cakupan Hubungan Interaksi Manusia

Sebagai makhluk yang paling sempurna, dari makhluk ciptaan Allah lainnya. Manusia memiliki kemampuan menjalin relasi lebih luas. Anchok (20II) menyebutkan sekurang-kurangnya ada empat ragam relasi manusia yang masing-masing memiliki kutup positif dan negatif, yaitu:

I) Hubungan manusia dengan dirinya, yang ditandai dengan oleh kesadaran untuk melakukan amar ma'ruf nahi munkar (S. 3: II0) atau sebaliknya mengumbar nafsu-nafsu rendah (S. 38: 6: 5; S. 45: 23).

2) Hubungan antar manusia dengan membina hubungan silahturahmi (S. 4: I) atau memutuskannya (S. 12: 100).

3) Hubungan manusia dengan alam sekitar yang ditandai upaya pelestarian dan pemanfaatan alam dengan sebaik-baiknya (S. II: 6) atau sebaliknya menimbulkan kerusakan alam (S. 30: 4I).

4) Hubungan manusia dengan sang pencipta dengan kewajiban ibadah kepadaNya (S. 5I: 56) atau menjadi ingkar dan syirik kepadaNya (S. 4: 48).

Bastaman (20II) pun menyatakan sekalipun manusia seakan-akan merupakan pusat hubungan-hubungan (center of relatedness), tetapi dalam ajaran Islam pusat segalanya bukanlah manusia, melainkan Sang Pencipta sendiri yaitu Allahu Robb'al'alamin. Maka, landasan filsafat mengenai manusia dalam ajaran Islam bukan Antroposentrisme. Melainkan Theosentrisme, atau lebih tepat Allah-sentrisme. Dengan demikian, dapat ditarik kesimpulan bahwa dalam pandangan Islam mengenai aktivitas maupun hubungan manusia baik dengan dirinya maupun dengan yang lain akan bernilai manakala Allah yang merupakan tujuan atau orientasi utamanya.

Pandangan Islam Mengenai Pengembangan Diri (Potensi) Manusia

Manusia merupakan mahkluk ciptaan Allah yang paling sempurna dibandingkan dengan makhluk Allah lainnya. Kesempurnaan itu terletak dari adanya akal yang lebih cerdas dari makhluk Allah lainnya. Allah telah menciptakan pada diri manusia beberapa potensi, diantaranya potensi iman, jasmani, rohani, dan nafsu (Bustaman: 201 I, Sutoyo: 2013, Sopiati \& Sahrani: 20 II, Najati: 200I). Berdasarkan potensi yang dimiliki manusia tersebut, terbentuklah karakteristik pada diri manusia yang begitu unik (yang berbeda 
dengan malaikat, iblis, hewan maupun tumbuhan). Sutoyo (2013; 20I5) menyebutkan beberapa karakteristik manusia diantaranya;

I) Diciptakan Allah dari dua unsur yang tidak bisa dipisahkan antara satu dengan yang lain, yaitu unsur jasmani dan Ruhh Illahi (akal dan ruhani)

2) Sejak awal kejadiannya sudah dilengkapi dengan "fitrah beragama" yaitu mengakui keesaan Allah dan tunduk kepada-Nya

3) Diciptakan Allah dilengkapi dengan akal pikiran, yang memungkinkan ia mampu membedakan antara yang benar dengan salah, yang bermanfaat dan tidak bermanfaat

4) Diciptakan Allah dilengkapi dengan perasaan yang memungkinkan manusia mengetahui hal-hal yang tersembunyi dan halus

5) Diciptakan Allah dilengkapi dengan hati nurani (fu'ad) dan qalb, tidak seperti hewan yang hanya dilengkapi dengan pendengaran dan penglihatan

6) Kemampuan manusia untuk mengetahui mengetahui beberapa hal sangat terbatas, kecuali sekedar tanda-tandanya

7) Tempat menetap manusia sebelum lahir di tulang sulbi ayah, dan setelah lahir di bumi, tempat penyimpanan sebelum lahir di dalam rahim ibu, dan setelah lahir ke dunia kemudian mati tempat penyimpanannya di kubur sebelum menuju kehidupan di surga atau neraka

8) Terhadap setiap individu ada dua malaikat yang selalu mengikutinya secara bergiliran di depan dan belakangnya mereka menjaganya atas perintah Allah

9) Gerak-gerik manusia selalu diawasi dan dicatat oleh dua malaikat, baik itu perbuatan baik atau buruk

10) Setiap individu akan mendapatkan balasan dari apa yang ia perbuat. Perbuatan yang baik dibalas dengan surga, dan yang tidak baik dibalas dengan siksaan Allah di neraka. Hal ini berbeda dengan binatang yang setelah mati tidak ada tanggungjawab lagi

Dengan demikian, manusia pun memiliki kelebihan dan juga kekurangan. Sutoyo (2015) mengatakan ada beberapa kelemahan manusia yang telah disebutkan dalam Alquran, namun diduga kuat kelemahan itu bersifat "potensial", artinya potensi negatif itu ada, tetapi bisa jadi menonjol pada sebagian orang, dan tidak pada oranglain, atau menonjol pada seseorang pada suatu saat, tetapi tidak menonjol pada saat yang lain. Disebutkan, perbedaan tersebut dikarenakan beberapa faktor diantaranya; tingkat ketaatan seorang terhadap ajaran agama, pendidikan pengalaman hidup, lingkungan pergaulan, 
bahkan bisa jadi karena kualitas (halal dan haram) makanan atau minuman yang dikonsumsinya sehari-hari. Beberapa karakter negatif manusia diantaranya: melalaikan ajaran agama, makhluk yang lemah, cenderung nakal, cenderung tergesa-gesa, cepat berputus asa dan tidak bertema kasih, suka membantah dan mencari-cari alasan, cenderung tamak, cenderung kikir, cenderung congkak, dan iri hati dan dengki. Dalam hal ini, Islam memandang manusia haruslah terus berusaha berbuat kebaikan untuk dirinya dan kehidupannya. Manusia terbaik ialah manusia yang mampu menjalankan ajaran Islam secara kafah sebagaimana yang dicontohkan oleh Rasulullah. Oleh karenanya, dengan segala keterbatasannya manusia harus sedia terus berusaha membangun diri untuk memperoleh keberuntungan di dunia dan di akhirat.

Apakah iman dan takwa hanya terkait akhirat semata? Tampaknya tidak begitu, telah disebutkan bahwa makna ibadah begitu luas, ada yang bersifat ritual (seperti sholat, puasan dII), namun ada juga ibadah yang digolongkan segala aktivitas baik manusia yang telah diniatkan untuk memperoleh ridho Allah. Contohnya, seorang mahasiswa yang belajar sungguh-sungguh untuk memperoleh ridho Allah. Islam tentu lebih mencintai Muslim yang rajin belajar dibanding yang malas belajar. Bahkan, Islam pun memberikan penghargaan yang tinggi bagi manusia yang berilmu.

Allah lebih menyukai Muslim yang kuat daripada yang lemah. Dalam hal ini, digambarkan Muslim yang kuat lebih memiliki daya bagi dirinya sendiri dan oranglain untuk lebih banyak berbuat atau mengajarkan kebaikan. Terkait hal ini, Islam begitu memenghargai waktu, oleh karenanya, hendaknya manusia jangan menyia-nyiakan waktu yang dimilikinya. Sebagaimana, Demi masa, sungguh, manusia berada dalam keraguan, kecuali orang-orang yang beriman dan mengerjakan kebajikan serta saling menasehatkan untuk kebenaran dan saling menasehatikan untuk kesabaran (Al Asr I-3). Mengenai ayat ini, Prayitno (2015) menangkap bahwa manusia (akan, atau sangat memungkinkan) merugi, setiap waktu, setiap saat, dalam kesehariannya; bahkan mungkin sepanjang hayatnya; kecuali orang-orang yang berada atau berperilaku dalam empat kondisi pokok, yaitu: I) Beriman; 2) Melakukan kebajikan, atau dengan kata lain beramal sholeh; 3) Melakukan hal-hal yang benar, atau dengan kata lain memenuhi hal-hal yang haq; 4) Melakukan sesuatu dengan kesabaran, atau dengan kata lain berperilaku sabar.

Oleh karena itu, hendaknya kita bisa memanfaatkan waktu dengan sebaiksebaiknya melalui aktivitas-aktivitas yang bermanfaat sehingga kelak memperoleh kebaikan dunia dan akhirat. Kita dapat menjalankan peran kita 
masing-masing pada jalan yang benar dan sesuai syari'at Islam. Jika apa yang kita lakukan tidak diniatkan karena Allah maka kita hanya memperoleh bagian dunia saja. Tetapi jika apa yang kita lakukan disertai niatan untuk memperoleh ridho Allah (biasanya aktivitas dimulai dengan menyebut basmalah) maka kita akan memperoleh bagian di dunia dan juga akhirat. Sebagaimana, Membangun harga diri dan mengembangkan potensi bagi seorang Muslim harus diarahkan kepada peningkatan keimanan dan ketaqwaan. (QS. Ali Imran/3: 139).

Bagi tiap-tiap umat ada kiblatnya (sendiri) yang ia menghadap kepadanya. Maka berlomba-lombalah (dalam membuat) kebaikan. Dimana saja kamu berada pasti Allah akan menumpulkan kamu sekalian (pada hari kiamat). Sesungguhnya Allah Maha Kuasa atas segala sesuatu (Al-Baqarah: 148). Berdasarkan ayat tersebut, tentu Islam tidak menghendaki umatnya memiliki sikap malas, jorok, dan berbuat buruk. Islam menyeru untuk banyak-banyaklah berbuat baik, yang kebaikannya nanti pun akan kembali untuk pelakunya. Allah tidak akan mengubah nasib suatu kaum sampai kaum itu sendiri yang mengubah nasib atau keadaan yang ada pada dirinya (QS Ar-Ra'd II). Hai manusia, sesungguhnya kamu telah bekerja dengan sungguh-sungguh menujut Tuhanmu, maka pasti kamu akan menemui-Nya (QS. Al-Insyiqaq: 6). Dapat dipahami bahwa kita harus bertanggungjawab akan diri kita. Mau dibawa kemana diri kita tergantung usaha kita dan kehendak Allah. Dan, Allah tidak akan mengubah nasib kita apabila kita hanya berpangku tangan.

Belajar Menurut Perspektif Pendidikan

Sebelum mengenali makna belajar menurut Islam, terlebih dahulu membahas makna belajar dalam sudut pandang pendidikan. Syah (2013) mengatakan belajar adalah tahapan perubahan seluruh tingkahlaku individu yang relatif menetap sebagai hasil pengalaman dan interaksi dengan lingkungannya. Slameto (2003: 5) menyatakan belajar adalah "suatu proses usaha yang dilakukan seseorang untuk memperoleh suatu perubahan tingkah laku yang baru secara keseluruhan, sebagai hasil pengalamannya sendiri dalam interaksi dengan lingkungannya. Lebih lanjut Abdillah dalam Aunurrahman (2010 :35) menyimpulkan bahwa "Belajar adalah suatu usaha sadar yang dilakukan oleh individu dalam perubahan tingkah laku baik melalui latihan dan pengalaman yang menyangkut aspek-aspek kognitif, afektif, dan psikomotorik untuk memperoleh tujuan tertentu". Dapat dipahami bahwa belajar merupakan fenomena perubahan perilaku yang tidak instans, melainkan membutuhkan proses pengalaman dalam diri individu dari interaksi dengan lingkungannya. Lebih rinci, 
Makmun (2009) menyebutkan beberapa ciri perubahan perilaku hasil belajar, meliputi:

I) Perubahan hasil belajar itu intensional, artinya perubahan perilaku dihasilkan oleh pengalaman yang berlangsung secara berulang atau latihan. Contohnya, seorang guru bimbingan dan konseling terlatih melakukan konseling setelah ia mengenal teori dan melakukan beberapa kali praktik konseling.

2) Perubahan hasil belajar itu positif, artinya hasil perubahan perilaku bernilai positif baik dari segi norma maupun segi siswa (tingkat abilitas dan bakat khusus, tugas perkembangan dan sebagainya). Contohnya, kemampun mahasiswa BK dalam melakukan konseling merupakan kemampuan yang positif dalam pandangan norma di masyarakat dan pembelajaran tersebut sesuai untuk perkembangan usia mahasiswa.

3) Perubahan hasil belajar itu efektif, artinya membawa makna tertentu bagi pelajar itu (setidaknya sampai batas waktu tertentu) relatif tetap dan setiap saat diperlukan dapat direproduksi dan dipergunakan seperti dalam pemecahan masalah (problem solving), baik dalam ujian, ulangan, dan sebagainya maupun dalam penyesuaian diri dalam kehidupan sehari-hari dalam rangka mempertahankan kelangsungan hidup.

Secara umum, istilah belajar memang ditandai dengan perubahan perilaku. Namun pengertian perubahan perilaku ini tidak dapat diartikan secara serampangan, akan tetapi perubahan perilaku sebagai hasil belajar memiliki ciri tersendiri, diantaranya; intensif, positif, dan efektif. Dapat disimpulkan belajar adalah upaya seseorang dalam berproses untuk memperoleh perubahan perilaku pada dirinya (koqnitif, afektif, psikomotor) yang bersifat intensif, positif dan efektif.

Aktivitas belajar peserta didik di sekolah berada dalam bingkai pendidikan. Sehingga pengalaman belajar peserta didik harus linier dengan tujuan pendidikan yang sesungguhnya. Pendidikan diartikan sebagai upaya mengembangkan kualitas pribadi manusia dan membangun karakter bangsa yang dilandasi nilainilai agama, filsafat, psikologi, sosial budaya, dan ipteks yang bermuara pada pembentukan pribadi manusia bermoral dan berakhlak mulia serta berbudi luhur (Natawijaya: 2007). Pendidikan merupakan suatu proses melumatkan dari kondisi apa adanya dengan kondisi bagaimana seharusnya untuk membantu peserta didik mencapai realisasi diri (Kartadinata, 20II). Realisasi diri mengandung arti sangat luas karena menyangkut masalah kesadaran individu terhadap dirinya sendiri maupun lingkungan sebagai lifespace-nya. Disebutkan 
pula, pendidikan adalah upaya normatif yang membawa manusia untuk merealisasikan diri (Kartadinata: 20 I I). Kesadaran diri individu terhadap diri dan lingkungannya mengandung arti pemahaman diri dan lingkungan sehingga menuntunnya untuk cakap dalam upaya penyesuaian diri secara normatif. Dengan demikian dapat dipahami bahwa pendidikan tidak saja membantu peserta didik menjadi pribadi yang berkompetensi baik dalam bidang akademik, tapi juga berkompetensi dalam bidang pribadi, sosial dan juga karier.

Belajar Menurut Perspektif Islam

Islam telah banyak memberikan anjuran pada manusia untuk belajar atau menambah pemahamannya, sebagaimana yang tertuang pada Alquran (96: I-5) menyebutkan bahwa Allah berfirman, "Bacalah dengan (menyebut) nama Tuhanmu yang menciptakan, Dia telah menciptakan manusia dari segumpal darah. Bacalah, dan Tuhanmulah Yang Maha Pemurah, Yang mengajar (manusia) dengan perantara kalam. Selain itu, berikut perintah tentang anjuran menyelidiki alam semesta, "Katakanlah, Perhatikanlah apa yaag ada di langit dan di bumi. tidaklah bermanfaat tanda kekuasaan Allah dan Rasul-rasul yang memberi peringatan bagi orang-orang yang tidak beriman" (Yunus: IOI). "Sesungguhnya dalam penciptaan langit dan bumi, dan silih bergantinya malam dan siang terdapat tanda-tanda bagi orang-orang yang berakal, (yaitu) orang-orang yang mengingat Allah sambil berdiri atau duduk atau dalam keadan berbaring dan mereka memikirkan tentang penciptaan langit dan bumi (seraya berkata): "Ya Tuhan Kami, Tiadalah Engkau menciptakan ini dengan sia-sia, Maha suci Engkau, Maka peliharalah Kami dari siksa neraka" (Ali Imran 190-191). Maka Apakah mereka tidak berjalan di muka bumi, lalu mereka mempunyai hati yang dengan itu mereka dapat memahami atau mempunyai telinga yang dengan itu mereka dapat mendengar? karena Sesungguhnya bukanlah mata itu yang buta, tetapi yang buta, ialah hati yang di dalam dada" (Al-Hajj 46). Ayat-ayat tersebut menyaratkan bahwa manusia hendaknya menggunakan karunia yang telah diberikan oleh Allah berupa panca indera untuk dapat terus belajar atau menambah pengetahuan dan pemahaman. Hendaknya karunia berupa pengetahuan dan pemahaman itu akan semakin menambah keimanan dan ketakwaannya. Oleh karenanya, dalam belajar pun perlu meluruskan niat yakni dengan membaca basmalah, untuk memperoleh ridho Allah.

Ayat-ayat berikut pun menganjurkan kita untuk senantiasa merenungkan tentang kejadian dimuka bumi, "Dan Apakah mereka tidak memperhatikan bagaimana Allah menciptakan (manusia) dari permulaannya, kemudian mengulanginya (kembali). Sesungguhnya yang demikian itu adalah mudah bagi 
Allah. Katakanlah: "Berjalanlah di (muka) bumi, Maka perhatikanlah bagaimana Allah menciptakan (manusia) dari permulaannya, kemudian Allah menjadikannya sekali lagi. Sesungguhnya Allah Maha Kuasa atas segala sesuatu." (Al 'Ankabuut 19-20). "Adakah orang yang mengetahui bahwasanya apa yang diturunkan kepadamu dari Tuhanmu itu benar sama dengan orang yang buta? hanyalah orang-orang yang berakal saja yang dapat mengambil pelajaran,"(Arra'd: 19). Hadist riwayat Abdullah bin Mas'ud bahwa Rasulullah SAW bersabda "Pelajarilah ilmu dan ajarkankah ia kepada orang-orang! Pelajarilah hal-hal yang fardu dan ajarkanlah ia pada orang-orang! Pelajarilah Alquran dan ajarkanlah ia kepada orang-orang.

Pertanyaan selanjutnya, apakah yang tergolong ilmu dalam pandangan Islam? Dalam rangka menjawab pertanyaan tersebut, maka perllu meninjau pandangan para cendikiawan Muslim tentang ilmu itu sendiri. Para cendikiawan Muslim memiliki klasifikasi ilmu itu sendiri, yang diantaranya tidak jauh berbeda. Al-Farabi (Bakar: 1998) mengatakan bahwa ada tiga dasar pengklasifikasian ilmu, diantaranya: I) The nobility of subject matter, 2) The profoundity of the proofs, 3) The immensity of the benefitd in that science or art. Adapun (ilmu atau seni) unggul karena besarnya manfaat dan dibutuhkan di setiap zaman dan oleh setiap bangsa, itu seperti ilmu-ilmu agama (ilm ash-shar'iyah). Adapun ilmu yang unggul karena kedalaman bukti (empirik), itu adalah seperti geometri (handasah). Dan terakhir, ilmu yang unggul lainnya karena kemanfaatan materinya, itu seperti astronomi (ilm an-nujum). Al-Ghazali berpendapat ilmu dapat dibagi menjadi 2 yakni; ilmu agama dan ilmu intelektual. Ilmu agama wajib di pelajari oleh setiap orang, sedangkan ilmu intelektual tidak wajib dipelajari oleh tiap orang, bila sudah ada orang lainnya yang mempelajarinya. Ilmu intelektual seperti ilmu-ilmu umum, tiap orang tidak wajib mempelajari semua ilmu umum tersebut, tetapi mereka hanya wajib mempelajari ilmu umum yang telah mereka pilih sesuai dengan bakat dan minatnya (Bakar: 1998). Qubt al din Ashirazi (Bakar: 1998) menyatakan bahwa ilmu dibagi menjadi dua yakni; I) ilmu filosofi, dan 2) ilmu bukan filosofi. Ilmu filosofi terdiri dari ilmu-ilmu umum, seperti; matematika, psikologi, astronomi, dan lainnya (baik dalam bentuk teori maupun praktik). Ilmu bukan filosofi ialah ilmu religius (agama), ilmu religius terbagi menjadi dua yakni: I) ilmu yang menekankan pada tujuan (maksud), dan 2) ilmu tentang sastra (Arab).

Dapat disimpulkan bahwa Islam mengakui keberadaan dua ilmu, baik agama (keislaman) maupun ilmu umum (seperti; matematika, psikologi, fisika, ekonomi, bimbingan dan konseling). Lebih lanjut, menurut Qubt al din ashirazi 
(Bakar: 1998) setiap manusia dianjurkan untuk menuntut ilmu, terutama ilmu agama (keislaman), sedangkan ilmu umum hanya sebagai suatu kekhususan, tidak diwajibkan bagi tiap orang mempelajari semua ilmu umum, jika sudah ada yang mempelajarinya. Manusia wajib mempelajari satu ilmu umum sebagai suatu keahlian baginya. Dengannya ia akan memperoleh manfaat dan bermanfaat bagi banyak orang.

Islam sangat menganjurkan umatnya untuk menuntut ilmu sebagaimana yang tersirat dalam beberapa ayat dan hadist. Agar aktivitas belajar menjadi nilai berharga bagi diri kita maka kita dianjurkan untuk meniatkan belajar sebagai aktivitas beribadah kepada Allah. Semua perbuatan baik yang diizinkan oleh Allah dapat dikategorikan kedalam ibadah. Dalam hal ini, kita juga perlu memperhatikan perihal niat. Sebagaimana sabda Rasulullah, "Sesungguhnya semua amal-amalan itu tergantung pada niat”. Imam Ibnu Hajar Al-'Asqalani mengatakan Sesungguhnya niat itu kembali pada ikhlas, dan ikhlas adalah satu untuk Yang Satu tiada sekutu bagi-Nya”. Islam memandang bahwa segala perbuatan baik (seperti belajar ilmu agama maupun umum) dapat dikategorikan ibadah manakala diniatkan lurus ikhlas karena untuk memperoleh ridho Allah.

\section{Pendidik Dalam Pandangan Islam}

Dalam pandangan Islam, guru atau pendidik merupakan seseorang yang mengajarkan pengetahuan yang bermanfaat bagi orang lain. Perintah untuk mengajarkan kebaikan ini ditujuan untuk semua individu Muslim, bahkan Islam memberikan penghargaan bagi orang yang bersedia mengajarkan kebaikan. Abu Umamah meriwayatkan bahwa Rasulullah SAW bersabda, "sesungguhnya Allah, para malaikat-Nya, dan penduduk langit maupun bumi, bahkan semut berada di dalam bebatuan bumi dan ikan paus di kedalaman laut, pasti akan mendoakan (kesejahteraan) bagi orang yang mengajarkan kebaikan orang lain.” Demikian pula, Al Fudhail bin lyadh meriwayatkan bahwa Rasulullah SAW bersabda, "orang alim yang mengamalkan ilmunya, akan dipanggil sebagai orang besar di alam malaikat." Dalam Alquran (62:2) Allah Ta'ala berfirman; Dia-lah yang mengutus kepada kaum yang buta huruf seorang Rasul diantara mereka, yang membacakan ayat-ayat-Nya kepada mereka, menyucikan mereka dan mengajarkan kepada mereka kitab dan hikmah. Dan sesungguhnya mereka sebelumnya benar-benar dalam kesesatan yang nyata. Dapat disimpulkan bahwa belajar dan mengajarkan kebaikan merupakan salah satu perintah dalam Islam bagi seluruh Muslimin. Bahkan, Islam memberikan penghargaan bagi orang yang sedia mengajarkan kebaikan. 
Mengajar merupakan tugas Rasulullah SAW dan sekaligus telah dicontohkan oleh Beliau di masa hidupnya. Rasulullah merupakan contoh seorang guru yang baik dan perlu dicontoh oleh setiap orang. Abu Daud meriwayatkan bahwa suatu hari seseorang berkata kepada Salman, "sesungguhnya Nabi kalian telah mengajarkan segala sesuatu kepada kalian bahkan sampai masalah kotoran." Salman menjawab, "Benar, sungguh Rasulullah SAW melarang kami untuk menghadap kiblat ketika sedang buang hajat atau kencing, Beliau juga menyarankan agar kami tidak beristinja dengan menggunakan tangan kanan, serta menyarankan agar salah seorang diantara kami tidak beristija dengan batu yang kurang dari tiga butir, atau juga beristinja dengan tinja dan tulang." Disebutkan pula, dalam riwayat Muslim, Abu Daudm dan Nasa'i (Syaibani) bahwa Mu'awiyah bin al Hakam as Sulami berkata , "Tidak kulihat ada seorang pun pengajar, sebelum dan sesudah Rasulullah, yang mengajarnya lebih baik dari Beliau". Najati (2008) memberi kesimpulan bahwa Rasulullah SAW merupakan seorang pengajar yang lemah lembut, mengajari manusia dengan ramah dan cara yang sederhana (mudah), beliau mampu membuka hati dan akal pikiran para sahabatnya sehingga ilmu pengetahuan yang disampaikan beliau meresap ke dalam jiwa mereka.

Allah SWT pun telah menganjurkan pada kita untuk meneladani Rasulullah. Surat Al-Ahzab (2I) berbunyi "Sesungguhnya Telah ada pada (diri) Rasulullah itu suri teladan yang baik bagimu (yaitu) bagi orang yang mengharap (rahmat) Allah dan (kedatangan) hari kiamat dan dia banyak menyebut Allah". "Dan tiadalah kami mengutus kamu, melainkan untuk (menjadi) rahmat bagi semesta alam" (QS.Al-Anbiya':I07). Rasulullah SAW bersabda: Aku diutus untuk menyempurnakan budi pakerti yang mulia" (H.R. Thabrani dari Jabir, dan Ahmad dari Mu'adz bin Jabal). Demikian, keteladanan nabi Muhammad SAW dapat dilihat dalam berbagai aspek perannya seperti, keteladanan sebagai pribadi Muslim, keteladanan sebagai pemimpin, keteladanan dalam hidup berumah tangga, keteladanan sebagai pendidik, dan lain sebagainya. Sifat-sifat Rasulullah yang paling khas diantaranya shiddiq (benar), fathonah (cerdas), tabligh (menyampaikan), dan amanah (dapat dipercaya). Oleh karenanya, kita sebagai hamba Allah (khususnya juga sebagai pendidik) selayaknya dapat meneladai keempat sifat Rasullullah tersebut.

Menurut Zakia derajat dalam Djamarah (2000) menjadi pendidik bukanlah hal yang mudah, tapi harus memenuhi beberapa syarat berikut: I) Takwa kepada Allah, 2) Berilmu, 3) Sehat jasmani, dan 4) Berkelakuan baik. Secara khusus, Ramayulis (2005) menyebutkan bahwa seorang pendidik harus 
menjalankan tugasnya dengan baik harus memenuhi beberapa syarat, diantaranya; syarat fisik, syarat psikis, syarat keagamaan, syarat tekhnis, syarat paedagogis, syarat administratif, dan syarat umur.

Betapa tidak mudah menjalankan tugas sebagai guru, oleh karenanya guru perlu dibekali komptensi yang memadai baik dalam hal pengetahuan, perasaan, dan keterampilan. Guru pun perlu bersedia untuk terus belajar sepanjang hayat sebagai bentuk pengembangan diri berkelanjutan. Meski demikian, Allah dalam firmannya telah mengungkapkan keistimewaan dan pahala bagi orang yang sedia mengajarkan ilmu atau kebaikan kepada oranglain (dengan niat karena Allah).

\section{Hakikat dan Tujuan Bimbingan dan Konseling}

Bimbingan dan Konseling di Indonesia lahir dilatarbelakangi oleh kebutuhan pendidikan. oleh karenanya, keberadaan bimbingan dan konseling turut menyempurnakan pendidikan di Indonesia. Mengulas kembali, tujuan pendidikan ialah mengembangkan kemampuan dan membentuk watak serta peradaban bangsa yang bermartabat dalam rangka mencerdaskan kehidupan bangsa, bertujuan untuk berkembangnya potensi peserta didik agar menjadi manusia yang beriman dan bertakwa kepada Tuhan Yang Maha Esa, berakhlak mulia, sehat, berilmu, cakap, kreatif, mandiri, dan menjadi warga negara yang demokratis serta bertanggung jawab (Undang-Undang No. 20, Tahun 2003). Tujuan pendidikan di Indonesia sejatinya tidak saja menekankan pada aspek pengetahuan saja, tetapi juga aspek perasaan dan juga keterampilan. Perasaan ini meliputi keyakinan kepada Tuhan dan sikap moral. Perseta didik diharapkan dapat menjadi pribadi yang berke-Tuhanan yang baik, bermoral, berpengetahuan dan berwawasan luas, terampil, mandiri, sehat baik fisik dan psikis. Untuk mewujudkan cita-cita tersebut, tidak cukup hanya melalui pembekalan materi pelajaran semata. Tetapi perlu keterampilan tentang pemahaman diri dan lingkungan (secara komprehensif). Tujuan pemahaman diri dan lingkungan ini ialah agar individu mamapu menyesuaikan diri, memilih keputusan yang tepat bagi masa depannya, memiliki pemahaman yang sehat dan baik tentang kehidupan dan berkembang secara sehat. Intinya bimbingan dan konseling membantu mengembangkan keterampilan hidup individu.

Bicara tentang bimbingan dan konseling tidak bisa terlepas dari pendidikan, karena bimbingan dan konseling ada di dalam pendidikan (Kartadinata, 2007). Lebih lanjut, pendidikan bertolak dari hakikat manusia dan merupakan upaya membantu manusia untuk menjadi apa yang bisa dia perbuat (doing) dan bagaimana dia harus menjadi (becoming) dan berada (being). Oleh 
karena itu, bimbingan dan konseling tidak cukup bertopang pada kaidah-kaidah psikologis, tetapi harus mampu menangkap eksistensi manusia sebagai makhluk Tuhan Yang Maha Kuasa. Keberadaan bimbingan dan konseling dalam pendidikan merupakan konsekuensi logis dari hakikat dan makna pendidikan itu sendiri. Esensi bimbingan dan konseling terletak pada proses memfalisitasi perkembangan individu di dalam lingkungannya. Perkembangan terjadi melalui interaksi secara sehat antara individu dengan lingkungan, oleh karena itu, upaya bimbingan dan konseling tertuju pula kepada upaya membangun lingkungan perkembangan manusia yang sehat (Kartadinata, 2007).

Secara khusus, Natawijaya dalam Yusuf (2008) menyebutkan bimbingan sebagai suatu proses pemberian bantuan kepada individu yang dilakukan secara berkesinambungan, supaya individu tersebut dapat memahami dirinya dan dapat bertindak secara wajar, sesuai dengan tuntutan dan keadaan lingkungan sekolah, keluarga, masyarakat, dan kehidupan pada umumnya. Sementara itu, Prayitno menyimpulkan bahwa bimbingan adalah bantuan yang di berikan kepada siswasiswa baik secara perorangan (individu) maupun kelompok agar mereka dapat berkembang menjadi pribadi-pribadi yang mandiri. Djumhur dan M. Surya memberikan batasan tentang bimbingan, yaitu suatu proses pemberian bantuan terus menerus dan sistematis kepada individu dalam memecahkan masalah yang di hadapinya, agar tercapai kemampuan untuk memahami dirinya sendiri (self understanding), kemampuan untuk menerima dirinya sendiri (self accaptance), kemampuan untuk mengarahkan diri sendiri (self direction) dan kemampuan untuk merealisir diri sendiri (realization), sesuai dengan potensi dan kemampuan dalam mencapai penyesuaian diri dengan lingkungan. Dapat dipahami bimbingan merupakan pemberian bantuan kepada individu maupun kelompok agar mereka lebih terampil dalam melakukan penyesuaian terhadap diri dan lingkungannya sehingga membentuk pribadi yang mandiri dan dinamis.

Sementara itu, Yusuf (2008) menyatakan konseling merupakan salah satu bentuk hubungan yang bersifat membantu, makna bantuan disini yaitu sebagai upaya untuk membantu oranglain agar ia mampu tumbuh ke arah yang dipilihnya sendiri, mampu memecahkan masalah yang dihadapinya dan mampu menghadapi krisis-krisis yang dialami dalam kehidupannya. Tugas konselor adalah menciptakan kondisi-kondisi yang diperlukan bagi pertumbuhan dan perkembangan klien. British Association of Counseling (BAC) dalam Mc Leod (2003) menjelaskan tugas konseling ialah memberi kesempatan kepada klien untuk mengeksplore, menemukan, dan menjelaskan cara hidup lebih memuaskan dan cerdas dalam menghadapi sesuatu. Berdasarkan pendapat para 
ahli tersebut, sepertinya konseling lebih memiliki arti spesifik. Konseling diperuntukan bagi individu yang memiliki masalah, dan peran konselor membantu individu (klien) tersebut dalam mengeksplore dirinya agar si klien menemukan keputusan atau pilihan terbaik untuk mengatasi masalahnya.

Dapat disimpulkan peran bimbingan dan konseling begitu mulia bagi kemaslahatan umat manusia. Bimbingan dan konseling bertujuan untuk membantu manusia agar berkembang lebih baik, sehat (fisik maupun psikis), mandiri, sejahtera, bermartabad, memiliki hubungan harmonis dengan sesama makhluk dan tentunya berke-Tuhanan Yang Maha Esa (terlebih di Indoensia yang merupakan negara ber-religi). Secara lebih khusus, bimbingan dan konseling memiliki beberapa bidang garapan dalam membantu perkembangan individu peserta didik, diantaranya bidang pribadi, sosial, belajar (akademik), dan karier. Diharapkan individu memiliki atau mengalami perkembangan yang sehat atau baik dan optimal baik dibidang pribadi, sosial belajar dan kariernya. Optimal bukan berarti maksimal atau mencapai tingkat paling tinggi pada kemampuan rata-rata manusia. Kondisi perkembangan optimum adalah kondisi dinamis yang ditandai dengan kesiapan dan kemampuan individu untuk memperbaiki diri (selfimprovement) agar dia menjadi pribadi yang berfungsi penuh (Fully Fuction person) di dalam lingkungannya (Kartadinata: 2007). Dapat disimpulkan perkembangan optimum memiliki ciri dimana individu dapat hidup bahagia dan mandiri dengan cara memanfaatkan potensi secara penuh. Perlu dipahami bahwa sangat memungkinkan potensi (baik di aspek pribadi, sosial, belajar, dan karier) setiap individu beraneka ragam tingkat maupun bentuknya.

\section{Bimbingan dan Konseling Belajar (Akademik) Dalam Perspektif Islam}

Pada bimbingan dan konseling belajar (akademik) disebutkan bahwa tujuan bimbingan dan konseling dikhususkan pada bidang belajar (akademik) yakni membantu perkembangan yang baik, sehat dan optimal dalam bidang belajar. Bimbingan akademik ialah bimbingan yang diarahkan untuk membantu para individu dalam menghadapi dan memecahkan masalah-masalah akademik (Yusuf, 2008), seperti: pengenalan kurikulum, pemilihan jurusan/konsentrasi, cara belajar, penyelesaian tugas-tugas dan latihan, pencarian dan penggunaan sumber belajar, perencanaan pendidikan lanjutan, dan lain-lain. Dalam hal ini, para guru bimbingan dan konseling perlu membantu individu mengatasi kesulitan belajar, mengembangkan cara belajar yang efektif, membantu individu agar sukses dalam belajar dan agar mampu menyesuaikan diri terhadap semua tuntutan program/pendidikan. Guru bimbingan dan konseling berupaya memfasilitasi individu dalam mencapai tujuan akademik yang diharapkan. Secara 
khusus, Yusuf (2008) menyebutkan tujuan-tujuan bimbingan dan konseling belajar, diantaranya ialah agar siswa dapat:

I) Memiliki sikap dan kebiasaan belajar positif, seperti kebiasaan membaca buku, disiplin dalam belajar, mempunyai perhatian terhadap semua kegiatan belajar yang diprogramkan.

2) Memiliki motif yang tinggi untuk belajar sepanjang hayat

3) Memiliki keterampilan atau teknik belajar yang efektif, seperti keterampilan membaca buku, menggunakan kamus, dan mencatat pelajaran

4) Memiliki keterampilan untuk menetapkan tujuan dan perencanaan pendidikan seperti, membuat jadwal belajar, mengerjakan tugas, memantapkan diri dalam memperdalam pelejaran tertentu, dan berusaha memperoleh informasi (melalui media cetak atau elektronik/internet) tentang berbagai hal dalam rangka mengembangkan wawasan yang lebih luas

5) Memiliki kesiapan mental dan kemampuan untuk menghadapi ujian

Senada dengan pendapat di atas, Djumhur dan Mohammad Surya (1978) menjelaskan bahwa "tujuan dari bimbingan belajar ialah membantu siswa agar mendapat penyesuaian yang baik dalam situasi belajar". Menurut Oemar Hamalik (1990) layanan bimbingan belajar merupakan suatu proses yang bertujuan: I) agar siswa bertanggung jawab menilai kemampuannya sendiri dan menggunakan pengetahuan mereka secara efektif bagi dirinya; 2) agar siswa menjalani kehidupan sekarang secara efektif dan menyiapkan dasar kehidupan masa depannya sendiri; 3) agar semua potensi siswa berkembang secara optimal meliputi semua aspek pribadinya sebagai individu yang potensial.

Menurut Skinner (Oemar Hamalik, 1990) bimbingan belajar bertujuan untuk menolong setiap individu dalam membuat pilihan dan menentukan sikap yang sesuai dengan kemampuan, minat, dan kesempatan yang ada yang sejalan dengan nilai-nilai sosialnya. Berdasarkan pendapat-pendapat tersebut, dapat disimpulkan bahwa bimbingan dan konseling belajar ialah upaya bimbingan dan konseling untuk membantu individu menemukan dan mengembangkan potensi belajarnya, serta menyesuaikan diri dengan lingkungan dan tugas-tugas belajar (akademik) nya. Dengan demikian, bimbingan dan konseling belajar (akademik) meliputi pengenalan lingkungan belajar (di sekolah, rumah dan masyarakat), pengenalan potensi diri dalam belajar, pemilihan jurusan/konsentrasi belajar, cara pengarahan dan pengembangan diri terkait potensi belajar, dan cara mengatasi permasalahan belajar. 
Telah diuraikan sebelumnya bahwa belajar merupakan pintu utamakan dalam memperoleh ilmu. Sebagaimana pencarian ilmu dalam pandangan Islam itu hukumnya wajib. Bahkan Islam memberi kedudukan yang istimewa bagi penuntut ilmu atau orang yang memiliki ilmu. Oleh karena itu, apabila guru bimbingan dan konseling menjadi jalan yang memudahkan seseorang untuk menuntut ilmu maka amatlah mulia peran guru bimbingan dan konseling tersebut. Demikian peran bimbingan dan konseling belajar (akademik) dalam membantu individu dalam belajar (menuntut ilmu). Sebagaimana hadits yang diriwayatkan Imam Tirmidzi, Rasulllah bersabda: "Sesungguhnya Allah, para Malaikat, seluruh penduduk langit dan bumi, bahkan hingga semut-semut di dalam lubangnya senantiasa bershalawat kepada para pengajar kebaikan di tengah umat manusia”. Selin itu, "Barangsiapa yang mengajarkan kebaikan maka baginya pahala mengajarnya dan pahala orang-orang yang melakukan kebaikan karena ilmu yang diajarkannya, tanpa mengurangi sedikitpun pahala yang Allah berikan kepada orang yang melakukan kebaikan tersebut. Dan barangsiapa yang mengajarkan keburukan maka baginya dosa mengajarnya dan dosa orang-orang yang melakukan keburukan karena ilmu yang diajarkannya, tanpa mengurangi sedikitpun dosa yang Allah timpakan kepada para pelaku keburukan tersebut" (HR imam Muslim). Surat Al Nahl ayat I25 disebutkan "Serulah ke jalan Tuhanmu (wahai Muhammad) dengan hikmat kebijaksanaan dan nasihat pengajaran yang baik, dan berbahaslah dengan mereka (yang engkau serukan itu) dengan cara yang lebih baik”. Guru bimbingan dan konseling dalam mejalankan pekerjaannya memiliki muatan kebaikan, dimana bila dilakukan secara baik dan dengan niat yang baik akan memperoleh pahala maupun kebaikan (di dunia dan di akhirat).

Ada beberapa layanan yang dapat dilakukan bimbingan dan konseling diantaranya; layanan dasar, layanan responsif, perencanaan individu dan dukungan sistem. Keempatnya dapat dimanfaatkan untuk pengembangan belajar peserta didik. Sebagaimana, pendekatan BK pada umumnya. Pendekatan bimbingan dan konseling belajar pun dapat menggunakan berbagai pendekatan psikologi seperti; pendekatan psikoanalisis, behvioral, humanistik, spiritual (transpersonal), bahkan pendekatan psikologi Islam. Pemilihan pendekatanpendekatan ini pun harus dilakukan secara bijak yakni; I) konselor harus memahami karakteristik dan fungsi keseluruhan pendekatan-pendekatan tersebut, 2) Konselor memahami tujuan bimbingan dan konseling serta tujuan pendidikan, 3) Konselor memiliki pemahaman yang komprehensif terkait hakikat dan perkembangan manusia, 4) konselor memahami permasalahan klien 
dan kebutuhannya, dan 5) konselor terampil dalam memilih pendekatan yang sesuai untuk masalah klien. Oleh karena itu, konselor atau guru bimbingan dan konseling perlu memiliki kemampuan yang mumpuni sebelum memiliki kewenangan melakukan praktik bimbingan dan konseling. Persiapan diri konselor atau guru bimbingan dan konseling ini terutama dibekali sejak di bangku kuliah SI bimbingan dan konseling.

\section{SIMPULAN}

Berdasarkan kajian ini dapat disimpulkan bahwa Islam begitu menghargai dan memuliakan orang-orang yang sedang belajar dan mengajarkan pengetahuan atau kebaikan kepada orang lain. Dengan demikian, guru memiliki kesempatan yang luas dalam memperoleh kebaikan dari Allah, karena sebagaimana tugasnya yakni belajar dan juga mengajarkan. Bimbingan dan konseling belajar merupakan bagian dari upaya guru bimbingan dan konseling untuk membantu dan memudahkan siswa dalam proses belajar (menuntut ilmu). Islam begitu menghargai seseorang yang mempermudah oranglain lain dalam suatu urusan yang baik (terlebih menuntut ilmu).

\section{REFERENSI}

Alquran

Al-Bantani, I. N. (1987). Nashaihul Ibad. Semarang: Toha Putra.

Al-Bayan. (20I I). Shahih Bukhari Muslim. Penerjemah Tim Jabal. Bandung: Jabal. Al-Ghazali, A. H. (2007). Minhaj al Abidin Ila al Jannah. Yogyakarta: Diva Press.

Alim, M. (2006). Pendidikan Agama Islam. Bandung: Remaja Rosdakarya.

Ash-Shiddieqy, H. (199I). Kuliah Ibadah. Yogyakarta: Bulan Bintang.

Amin, S. M. (20I3). Bimbingan dan Konseling Islam. Jakarta: Amzah.

Arsyad, A. (20II). Media Pembelajaran. Jakarta: Rajawali Pers.

Arikunto, S. (1993). Manajemen Pengajaran Secara Manusiawi. Jakarta: Rineka Cipta.

Aunurrahman. (2010). Belajar dan Pembelajaran. Bandung: Alfabeta

Bakar, O. (1998). Classification Of Knowledge in Islam: A Study in Islamic Philosophies of Science. Cambridge: The Islamic Texs Society. 
Bustaman, H. D. (20II). Integrasi Psikologi dengan Islam. Yogyakarta: Insan Kamil.

Corey, G. (1990). Teori dan Praktik Konseling dan Psikoterapi. Penerjemah Muliarto: IKIP Semarang Press: Semarang.

Djamarah, S. B. (2000). Guru dan Anak Didik Dalam Interaksi Edukatif. Jakarta: Rineka Cipta.

Djumhar, \& Surya, M. (1978). Bimbingan dan Penyuluhan di Sekolah (Guidance \& Counseling). Bandung: Ilmu.

Frederickson, L. M., \& Anderson, D. H. (1999). A qualitative exploration of the wilderness experience as a source of spiritual inspiration. Journal of Environmental Psychology, 19, 21-39.

Hamalik, O. (1990). Pengembangan Kurikulum (Dasar-dasar Pengembangan). Mandar Maju: Bandung.

Jalal, A. F. (1988). Minal Ushulit Tarbawiyyah Fil Islam. Alih bahas: Hery Noer Ali. Azas-azas Pendidikan Islam. Bandung: Diponegoro.

Jamaludin, Komarudin, A., \& Khoerudin, K. (20I5). Pembelajaran Perspektif Islam. Bandung: Rosdakarya.

Kartadinata, S. (20I I). Menguak Tabir Bimbingan dan Konseling Sebagai Upaya Pedagogis. Bandung: UPI Press.

Makmun, A. S. (2009). Prinsip-Prinsip Diagnosis Kesulitan Belajar. Bandung: Rosda Karya.

Mu'awanah, Elfi, \& Hidayah, R. (2009). Bimbingan dan Konseling Islami. Jakarta: Bumi Aksara.

Najati, M. U. (200I). Alquran dan Psikologi. Jakarta: Aras Pustaka.

Najati, M. U. (2008). The Ultimate Psychology. Bandung: Pustaka Hidayah.

Natawidjaya, R., Sukmadinata, N. S, Ibrahim, R., Djohar, A. (Editors). (2007). Rujukan Filsafat, Teori dan Praksis IImu Pendidikan. Bandung: UPI Press.

Prayitno. (20I5). Keluhuran IQRA untuk kehidupan. Graha Cipta Media: Bogor.

Prayitno., \& Amti, E. (20I5). Dasar-Dasar Bimbingan dan Konseling. Jakarta: Rineka Cipta.

Shapiro, S. I., Lee, G. W., \& Gross, P. L. (2002). The essence of transpersonal psychology: Contemporary views. The International Journal of Transpersonal Studies, 21, 19-32. 
Shihab, M. Q. (2000). Wawasan Alquran. Tafsir Maudhu'i atas Berbagai Persoalan Umat. Bandung: Mizan.

Ramayulis. (2005). Metodologi Pendidikan Agama Islam. Jakarta: Kalam Mulia.

Slameto. (2003). Belajar dan Faktor-Faktor yang Mempengaruhinya. Jakarta: Rineka Cipta.

Sopiatin, P., \& Sahrani, S. (20I I). Psikologi Belajar dalam Perspektif Islam. Bogor: Ghalia Indonesia.

Sutoyo, A. (20I3). Bimbingan dan Konseling Islami (Teori dan Praktik). Pustaka Pelajar: Yogyakarta.

Sutoyo, A. (20I5). Manusia Dalam Perspektif Alquran. Yogyakarta: Pustaka Pelajar.

Syah, M. (2013). Psikologi Belajar. Jakarta: Raja Grafindo.

Syukur, A. (2012). Tasawuf Kontekstual. Yogyakarta: Pustaka Pelajar.

Yusuf, S. (2009). Proram Bimbingan dan Konseling di Sekolah. Bandung: Rizkipress.

Yusuf, S., \& Nurihsan, J. (2009). Landasan Bimbingan dan Konseling. Bandung: Rosdakarya.

Undang-Undang Dasar 1945.

Undang-Undang Republik Indonesia No 20 tahun 2003.

Tim Penyusun. (2009). Kurikulum Nasioanl Program Studi Bimbingan dan Konseling. ABKIN: Surabaya.

Syukur, A. (2003). Pengantar Studi Islam. Semarang: Bima Sakti. 